\title{
Central variant reversible encephalopathy syndrome
}

\author{
Dinesh Mohan Chaudhari, ${ }^{1}$ Pushpendra Nath Renjen, ${ }^{1}$ Nidhi Goyal $\odot{ }_{1}{ }^{2}$ Anjali Mishra ${ }^{3}$
}

${ }^{1}$ Neurology, Indraprastha Apollo Hospital, New Delhi, Delhi, India ${ }^{2}$ Radio Diagnosis, Indraprastha Apollo Hospital, New Delhi, Delhi, India

${ }^{3}$ Critical Care Medicine, Holy Family Hospital, Okhla Road, New Delhi, Delhi, India

\section{Correspondence to}

Professor Pushpendra Nath Renjen; pnrenjen@hotmail.com

Accepted 30 December 2021

\section{DESCRIPTION}

A 28-year-old female patient who did not have any systemic disease before presented with complaints of sudden onset of abnormal jerky movements of all limbs along with tongue bite lasting for about $10 \mathrm{~min}$. She had history of caesarean section 1 week back. Neurological examination revealed no focal neurological deficit. Her routine blood investigations and cerebrospinal fluid analysis were normal. MRI of brain showed areas of altered signal intensity (areas of T2 and FLAIR hyperintensities) involving bilateral basal ganglia, along cortical and subcortical regions predominantly along posterior aspect involving bilateral parieto-occipital lobes and left frontal lobe representing vasogenic oedema. There was also involvement of left cerebellar region

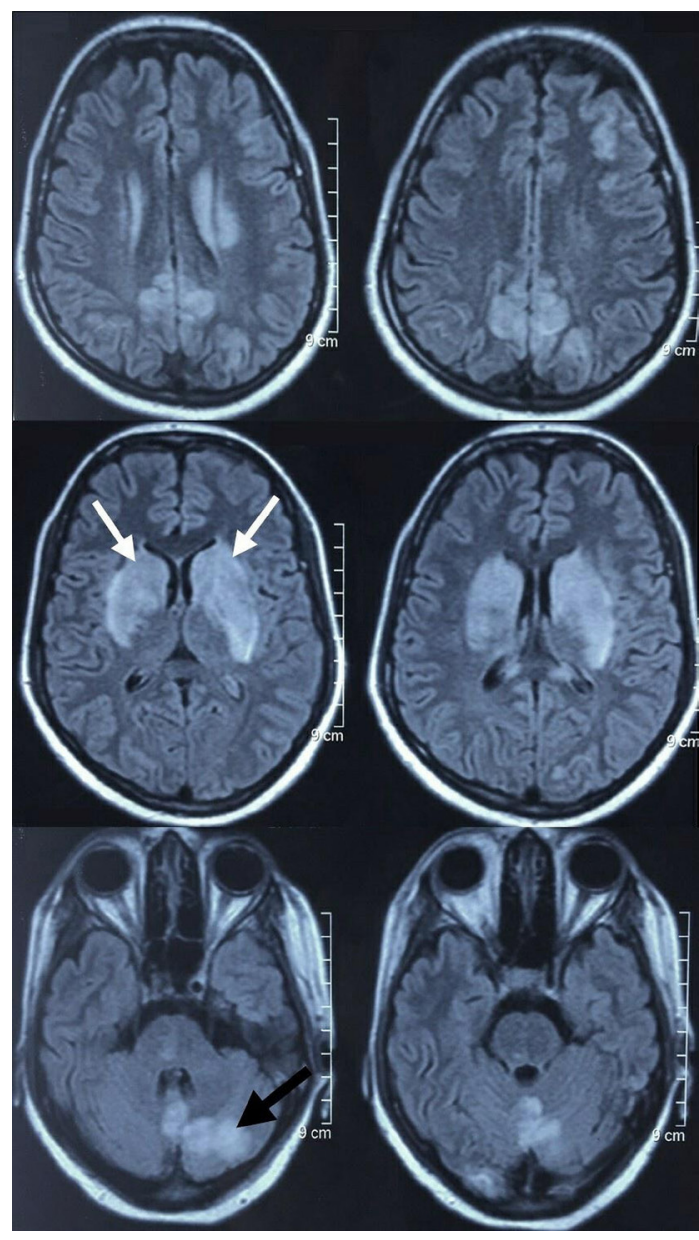

Figure 1 MRI of brain showing areas of altered signal intensity (areas of T2 and FLAIR hyperintensities) involving bilateral basal ganglia (white arrows), along cortical and subcortical regions predominantly along posterior aspect involving bilateral parieto-occipital lobes, left frontal lobe left cerebellar region (black arrow) and vermis.

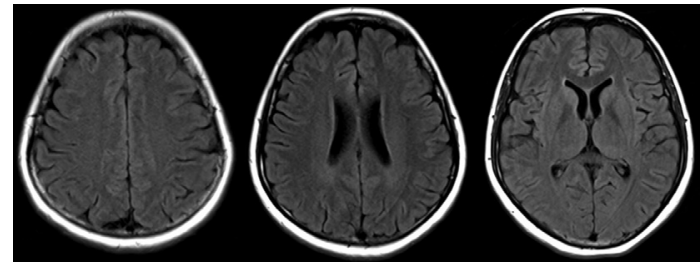

Figure 2 Repeat MRI brain on follow-up after 8 weeks showing near complete resolution of the lesions.

and vermis (figure 1). These MRI changes were suggestive of vasogenic oedema secondary to cerebrovascular autoregulatory dysfunction which was consistent with the diagnosis of postpartum central variant of reversible encephalopathy syndrome (PRES). ${ }^{12}$ The patient was treated with intravenous levetiracetam, intravenous phenytoin and supportive care, she responded well to treatment and did not have any further seizures or neurological issues. Repeat MRI brain on follow-up after 8 weeks revealed near complete resolution of the lesions (figure 2).

The central variant of PRES has been described in past as 'hypertensive brainstem oedema encephalopathy', 'hypertensive brainstem encephalopathy', 'reversible pontine oedema', 'reversible brainstem hypertensive encephalopathy' or 'brainstem hyperintensity in arterial hypertension'. ${ }^{3}$ These labels are confusing because PRES doesn't need hypertension as a cause and it is not limited solely to brainstem involvement. Hence it is proposed that terms like 'central variant PRES' or 'central reversible encephalopathy syndrome' are more appropriate, particularly because central structures other than the brainstem can also be involved in this variant. Central variant PRES was reported for the first time in 2010 the setting of systemic lupus erythematosus. ${ }^{4}$ There are no established risk factors which predispose patients to atypical variant of PRES. As per available literature, the differential diagnosis for current case included inflammatory demyelination, osmotic myelinolysis syndrome, infiltrative glioma, lupus-associated central nervous system vasculitis, reversible cerebral vasoconstriction syndrome and rhomboencephalitis. ${ }^{5}$ The pathophysiological process in central variant PRES is suggested to be the endothelial cell dysfunction occurring within smaller, perforating vessels supplying the brainstem and basal ganglia. ${ }^{3}$

Contributors DMC prepared the manuscripts and collected the MRI. PNR provided the clinical data of the patient and served as primary neurologist. NG provided the detailed radiology inputs. AM supervised the study concept and reviewed the manuscript and image findings of the case. 


\section{Learning points}

- Posterior cerebral distribution of reversible encephalopathy syndrome (PRES) has been well known but one needs to be aware of its central variant

- This entity is largely reversible, hence utmost care should be taken to avoid misdiagnosis and inappropriate management of central variant of PRES.

Funding The authors have not declared a specific grant for this research from any funding agency in the public, commercial or not-for-profit sectors.

Competing interests None declared.

Patient consent for publication Consent obtained directly from patient(s).

Provenance and peer review Not commissioned; externally peer reviewed.

Case reports provide a valuable learning resource for the scientific community and can indicate areas of interest for future research. They should not be used in isolation to guide treatment choices or public health policy.

\section{ORCID iD}

Nidhi Goyal http://orcid.org/0000-0002-2022-0073

\section{REFERENCES}

1 Marcoccia E, Piccioni MG, Schiavi MC, et al. Postpartum posterior reversible encephalopathy syndrome (PRES): three case reports and literature review. Case Rep Obstet Gynecol 2019;2019:1-11.

2 Hobson EV, Craven I, Blank SC. Posterior reversible encephalopathy syndrome: a truly treatable neurologic illness. Perit Dial Int 2012;32:590-4.

3 McKinney AM, Jagadeesan BD, Truwit CL. Central-variant posterior reversible encephalopathy syndrome: brainstem or basal ganglia involvement lacking cortical or subcortical cerebral edema. AJR Am J Roentgenol 2013;201:631-8.

4 Bag AK, Curé JK, Sullivan JC, et al. Central variant of posterior reversible encephalopathy syndrome in systemic lupus erythematosus: new associations? Lupus 2010:19:225-6.

5 Abraham P, Longardner K, Chen P, et al. Case 279: Central-Variant posterior reversible encephalopathy syndrome. Radiology 2020;296:239-43.

Copyright 2022 BMJ Publishing Group. All rights reserved. For permission to reuse any of this content visit

https://www.bmj.com/company/products-services/rights-and-licensing/permissions/

BMJ Case Report Fellows may re-use this article for personal use and teaching without any further permission.

Become a Fellow of BMJ Case Reports today and you can:

- Submit as many cases as you like

- Enjoy fast sympathetic peer review and rapid publication of accepted articles

- Access all the published articles

- Re-use any of the published material for personal use and teaching without further permission

\section{Customer Service}

If you have any further queries about your subscription, please contact our customer services team on +44 (0) 2071111105 or via email at support@bmj.com.

Visit casereports.bmj.com for more articles like this and to become a Fellow 